\title{
Anatomical Study of Pachyphragma macrophyllum (Hoffm.) N. Busch.
}

\author{
VV Fedotova, DA Konovalov*, AA Kruglaya
}

VV Fedotova, DA Konovalov*, AA Kruglaya

Department of Pharmacognosy, Botany and Technology of Phytopreparations, Pyatigorsk Medical and Pharmaceutical Institute, a Branch of Volgograd State Medical University Ministry of Health of Russian Federation, Pyatigorsk, 357532, Kalinina 11, RUSSIA.

\section{Correspondence}

\section{DA Konovalov}

Pyatigorsk Medical and Pharmaceutical Institute, Pyatigorsk, 357532, Kalinina 11 RUSSIA.

E-mail: d.a.konovalov@pmedpharm.ru History

- Submission Date: 03-09-2019;

- Review completed: 25-09-2019;

- Accepted Date: 01-10-2019.

DOI : 10.5530/pj.2019.11.242

Article Available online http://www.phcogj.com/v11/i6s

\section{Copyright}

(C) 2019 Phcogj.Com. This is an openaccess article distributed under the terms of the Creative Commons Attribution 4.0 International license.

\section{ABSTRACT}

Introduction: Pachyphragma macrophyllum (Hoffm.) N. Busch is not studied endemic of the Caucasus (Russia) and Turkey. Now in medicine, it is not applied yet, but preliminary data confirm potential use of this plant. For this purpose, it is necessary to carry out the analysis of $P$. macrophyllum, and we began with morphological, anatomic studying. Materials and Methods: P. macrophyllum herb was collected during the flowering period on the Mount Mashuk in Pyatigorsk, Stavropol region, Russia in April 2019. The anatomical structure of $P$. macrophyllum is considered in accordance with the requirements of the State Pharmacopoeia XIV. Results: The main morphological signs of P. macrophyllum: basal leaves have petioles; cordate or reniform. Stem leaves oval, petioles short. The leaves have a serrated margin. The inflorescences grow in a raceme. Fruit cordate silicula. Microscopic signs: on the edge of the leaf blade are outgrowths, walls of cells of the upper and lower epidermis heavily sinuous, stomata as a rule anisocytic type. In cross-section of the leaf, two types of mesophyll: palisade and spongy; vascular bundle collateral round shape. On the cross-section of the stem, the epidermis, collenchyma, parenchyma, collateral vascular bundles are located around. Cells of epidermis of a petal and sepal of a flower polygonal. Conclusion: The received standards will provide reference information for identification, purity, standardisation for the use of $P$. macrophyllum as raw materials for medicines.

Key words: Collenchyma, Cross-section, Mesophyll, Outgrowths on the edge of the leaf, Pachyphragma macrophyllum, Stomata anisocytic type, Vascular bundle.

\section{INTRODUCTION}

Pachyphragma is a monotypic genus of the fam. Brassicaceae. Pachyphragma macrophyllum (Hoffm.) N. Busch. is endemic to the Caucasus of Russia $^{1}$ and Turkey. ${ }^{2}$ Grows in shady broad-leaved forests in the mountains at the height up to 1700 $m$ in the Caucasus: Ciscaucasia, Dagestan. ${ }^{1}$ The plant was naturalised in England (Co. Avon). ${ }^{3}$ By the chromatographic analysis, it was established that the flowers contain six, and the leaves four, flavonoid compounds. From them, two are identified: kaempferol and trifolin. ${ }^{4}$ Alkaloids are found in the grass. ${ }^{5}$ The plant smells of garlic when bruised that is caused most likely by thioglycosides. The pharmacological activity of $P$. macrophyllum is not established, but Pachyphragma genus closely related to Thlaspi. ${ }^{6}$ Thlaspi arvense is characterised by antibacterial ${ }^{5}$, antiplasmodial effects. ${ }^{7}$ In our article, for the first time, an anatomical study of P. macrophyllum growing in Russia is given. This is necessary for the pharmacognostic analysis of raw materials, establishing its authenticity for the further preparation of medicines for use in pharmacy.

\section{MATERIAL AND METHODS}

The herb of P. macrophyllum was an object of this research. The herb was torn off in Pyatigorsk, Stavropol region in April 2019 during the blossoming of the plant (Figure 1).
The anatomical structure of $P$. macrophyllum was examined by previously published methods ${ }^{8}$ and requirements of the State Pharmacopoeia XIV. ${ }^{9}$ The material was fixed in the system ethyl alcoholglycerol-water in the ratio 1: 1: 1, also used fresh raw materials. Micropreparations were studied on a microscope "Biomed", lenses $\times 4, \times 10$, eyepiece $16 \times$. Microphotographs were made on a digital camera «3.0mp cmos microscope eyepiece new».

\section{RESULTS}

\section{Morphological study}

P. macrophyllum is a perennial herb $20-40 \mathrm{~cm}$ high Basal leaves have petioles, and bases dilated; cordate or reniform, $4-12 \mathrm{~cm}$ long and width. There are no hairs, more rare petioles and veins of young leaves pubescent. Stem leaves oval, petioles short. The leaves have a serrated margin. The inflorescence a raceme, the length is $3-6 \mathrm{~cm}$, sepals ovate green with white margin $3 \mathrm{~mm}$, petals white $8-10 \mathrm{~mm}$. Fruit cordate silicula.

\section{Microscopic study of the leaf}

The upper epidermis of the leaf, in frontal view (Figure 2A), has walls of cells heavily sinuous. There are stomata anisocytic type (cells around stomata 3 , one of them is small) and rarely stomata of the anomocytic type (cells around stomata $4-5$, they do not differ from other cells of the epidermis). The stomata are located on a par with the epidermis. 


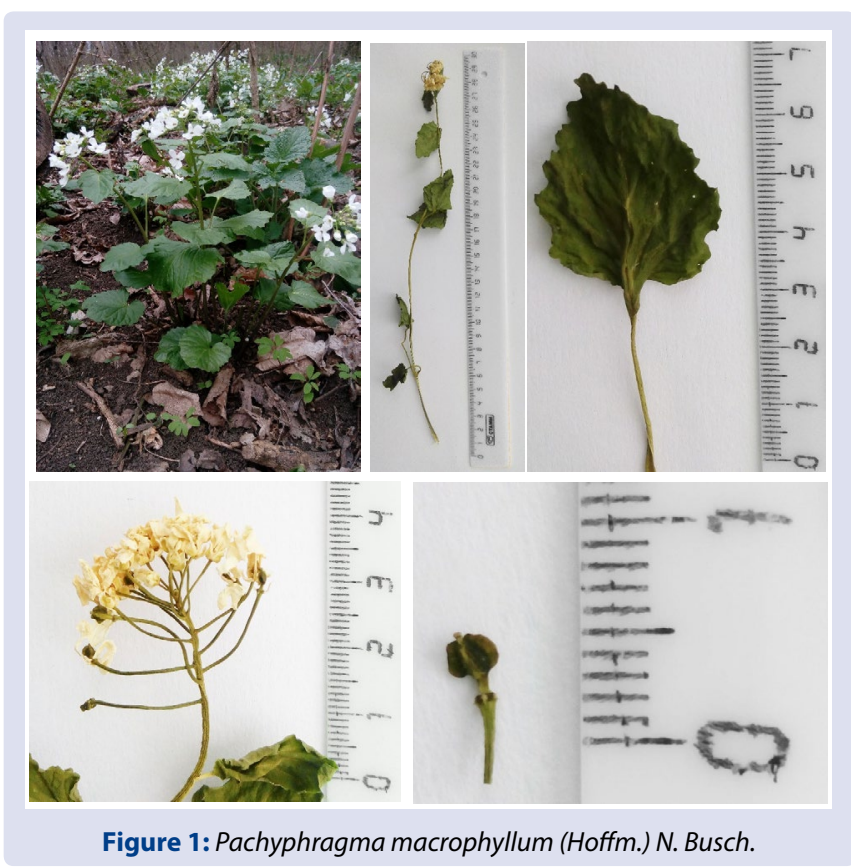

There are outgrowths on the edge of the leaf (Figure 2C). The lower epidermis differs from the upper epidermis by a large number of stomata (Figure 2B).

\section{Cross-sections of the leaf (Figure 2D)}

On a lower side of a leaf veins are well visible (Figure 2D). Cells of the upper and lower epidermis near the vein of rounded shape, in other part of the leaf - rectangular, are densely located in one layer, stomata rare.

Two types of parenchymal tissue (palisade and spongy) were found in leaf mesophyll (Figure 2E). Palisade mesophyll is located under the upper epidermis; this is 1-2 layers of rectangular cells; cells contain large amounts of chloroplasts, cell walls are thin. The spongy mesophyll is located between the palisade mesophyll and the lower epidermis. It consists of round or oval cells with the same number of chloroplasts as in the palisade mesophyll cells.

Under the lower epidermis, the collenchyma is located. A sizeable vascular bundle is located in the centre of the vein. The vascular bundle of rounded shape, the type is collateral, open. The xylem and phloem are almost equal in volume (Figure $2 \mathrm{~F}$ ). The sclerenchyma is near phloem. The parenchyma is located throughout the rest of the vein cells of the parenchyma of round or multi-faceted shape.

\section{Cross-sections of the stem (Figure 3A)}

The tissue covering of the stem is the epidermis. The epidermis consists of 1-2 layers of square cells with cuticle and thin walls; cells are close to each other on the epidermis rarely located simple multicellular hairs.

Collenchyma is 2-3 layers of cells; chloroplasts are present in many cells. The parenchyma is after the collenchyma; it consists of 4-6 rows, cells of different sizes, rounded shape, chloroplasts are present in small quantities in parenchyma cells (Figures 3B-3C).

Vascular bundles 15, are arranged in a circle (Figure 3A). Cambium is contained in the collateral vascular bundle, ovate shape (Figure 3D). The sclerenchyma is near phloem. Parenchyma occupies the rest of the stem, its cells of different sizes, round and oval.

\section{Cross-sections of the petiole (Figure 3E)}

The epidermis is tissue covering of the petiole - square epidermal cells with cuticle. Collenchyma is under the epidermis; it consists of 2-3 rows of round or oval cells; many cells contain chloroplasts (Figure 3F). Next is the parenchyma, many parenchyma cells also contain chloroplasts. Vascular bundles 5 (Figure 3E), collateral. Phloem is a small sieve elements. Xylem vessels of different sizes. Sclerenchyma is located near the xylem and phloem.

\section{Anatomical structure of the flower}

The epidermal cells of the petal are polygonal; the walls are straight (Figure 4A). Microscopy of the sepal detected vessels (Figure 4B). There were 3 (tricolpate) apertures in pollen (Figure 4C).

\section{DISCUSSION}

The main microscopic signs of $P$. macrophyllum are heavily sinuous walls of cells of the upper and lower epidermis, stomata as a rule anisocytic type, outgrowths on the edge of the leaf. In the cross-section of the leaf blade, two types of mesophyll: palisade and spongy; vascular bundle round shape, the type is collateral, open. The cross-section

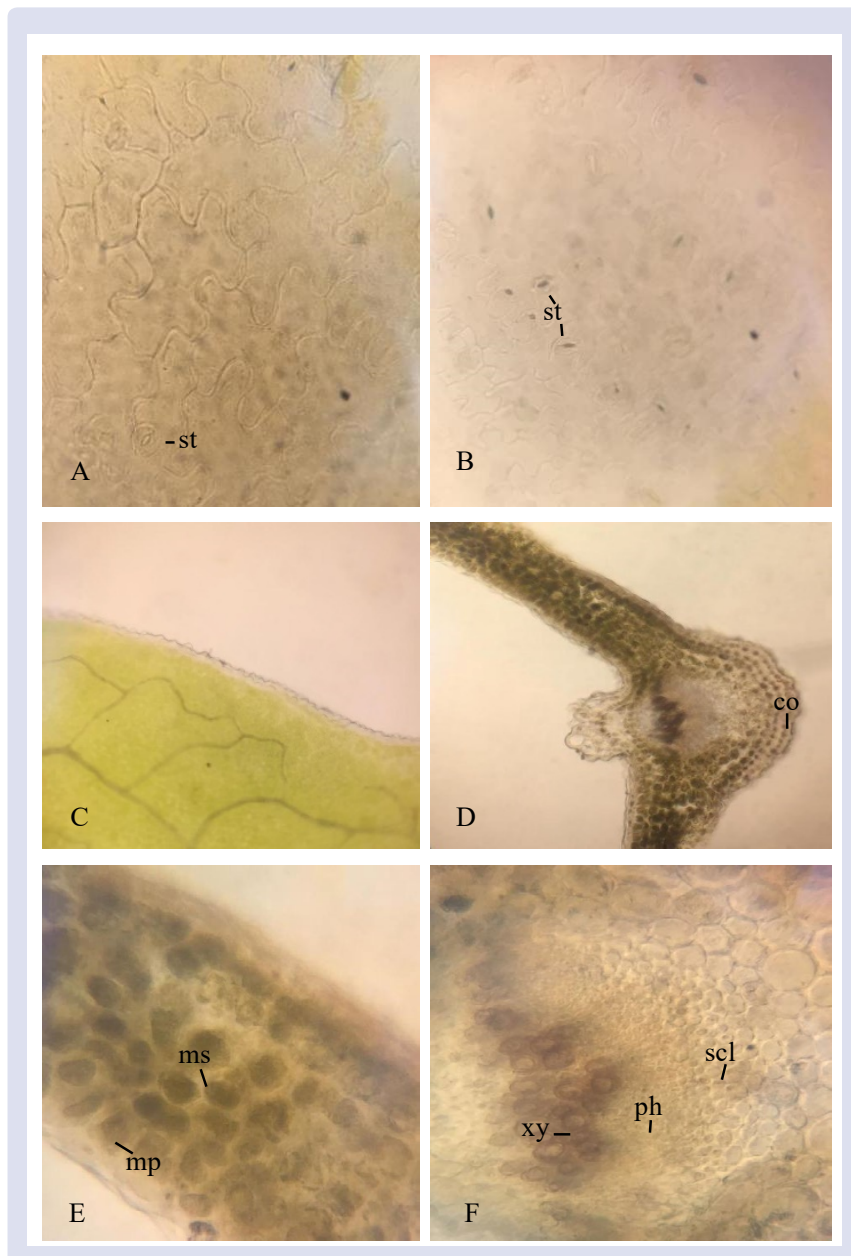

Figure 2: Leaf of $P$. macrophyllum: A - upper epidermis (640x); B lower epidermis (640X); $C$ - outgrowths on the edge of the leaf (160X); $D$ - leaf cross section (160x); E - leaf cross section (640x); F - vascular bundle (640X): st - stomata, co - collenchyma, $\mathrm{mp}$ - mesophyll palisade, ms - mesophyll spongy, xy - xylem, ph - phloem, scl - sclerenchyma. 


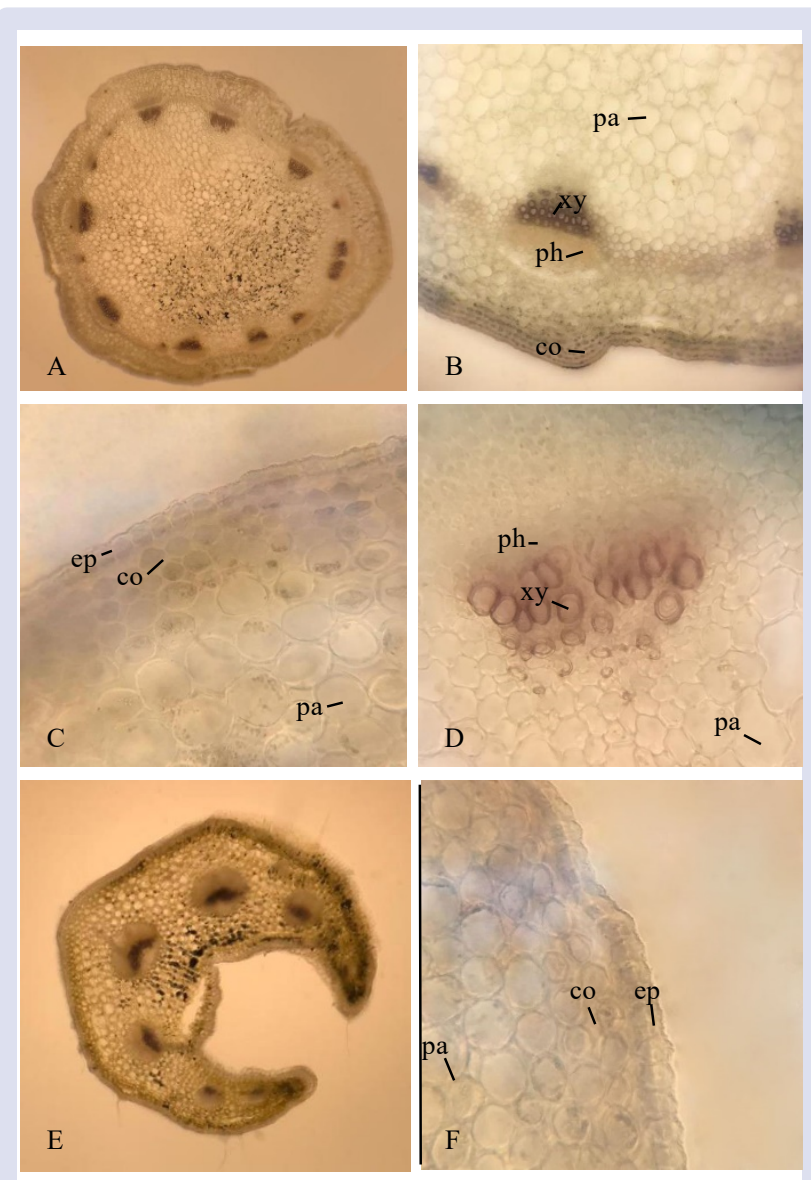

Figure 3: Cross-sections of the stem (A - 64x; B - 160x; C -640x; $D-640 x)$ and petiole ( $E-64 x ; F-640 x)$ of $P$. macrophyllum: ep - epidermis, co - collenchyma, xy - xylem, ph - phloem, pa parenchyma.

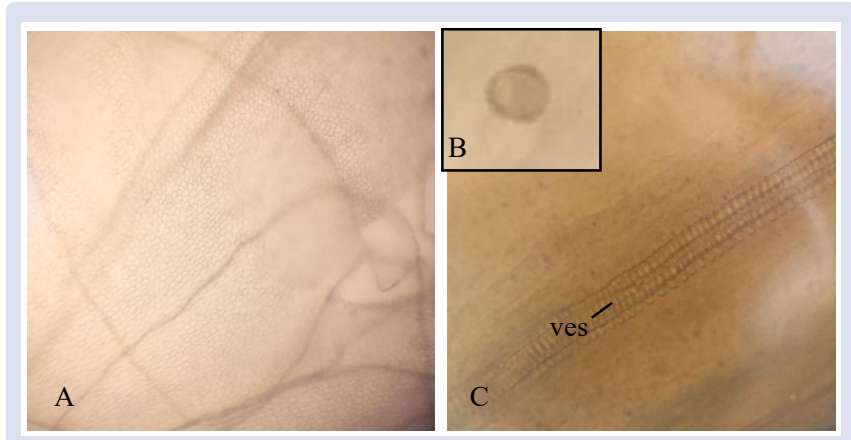

Figure 4: Flower of P. macrophyllum: A - epidermis of petal $(640 \times)$; B pollen grains $(640 \times)$; C - epidermis of sepal (1600x): ves - vessels. of the stem is characterized by epidermis, collenchyma, parenchyma. Collateral vascular bundles are located around. Sclerenchyma is located near the phloem. Cells of epidermis of a petal and sepal of a flower polygonal. The description of the stem and lamina is given for the plant growing in Turkey. ${ }^{10}$ This coincides with the characteristics of the plant from Russia.

\section{CONCLUSION}

The research is devoted to the pharmacognostic evaluation of $P$. macrophyllum. The article presents the morphological and microscopic signs of the plant. This research provides useful information for the correct identification, purity and standardisation of plants. Besides, the results of the study will be included in the preparation of the monograph of P. macrophyllum.

\section{CONFLICTS OF INTEREST}

The authors have no conflicts of interest to declare.

\section{ACKNOWLEDGEMENTS}

The authors are grateful to the head of Pyatigorsk medical and pharmaceutical Institute V. L. Adgienko.

\section{REFERENCES}

1. Komarov VL. Editor. Flora USSR VIII. Moscow: Edition of the Academy of Sciences. 1939.

2. Karaismailoğlu MC. Pachyphragma macrophyllum (Brassicaceae) türünün türkiye'de dağilişi ve taksonomik durumu. XII ulusal ekoloji ve çevre kongresi. Muğla; 2015:246

3. Davie JH, Akeroyd JR. Pachyphragma macrophyllum (Hoffm.) Busch(Cruciferae), a Caucasian species naturalized in Co. Avon, England. Botanical Journal of the Linnean Society. 1983;87:77-82.

4. Zemtsova GN, Dzhumyrko SF. Flavonoids of Pachyphragma macrophyllum Chemistry of Natural Compounds. 1974;10(5):689.

5. Sokolov PD. Editor. Plant resources of the USSR: Flowering plants, their chemical composition, the use. Paeoniaceae - Thymelaeaceae. St. Petersburg: Science. 1985.

6. Mummenhoff K, Coja U, Briiggemann H. Pachyphragma and Gagria (Brassicaceae) revisited: molecular data indicate close relationship to Thlaspi S.STR. Folia Geobotanica. 2001;36:293-302.

7. Walter NS, Bagai U. Antiplasmodial potential of traditional medicinal plant Thlaspi arvense. European Journal of Medicinal Plants.2014;4(12):1378-87.

8. Serebryanaya FK, Zayer G. Micromorphological analysis of the aerian organes of Marrubium alysson L. from flora of Tunisia. Pharmacy \& Pharmacology. 2018;6(5):462-74

9. State Pharmacopoeia of the Russian Federation. 14th ed. Ministry of Health RF; 2018.

10. Karaismailoğlu MC. Taxonomical, morphological, palynological, anatomical and ecological investigations on monotypic genus Pachyphragma from Turkey. Pak J Bot. 2019;51(3):1021-6. 


\section{GRAPHICAL ABSTRACT}

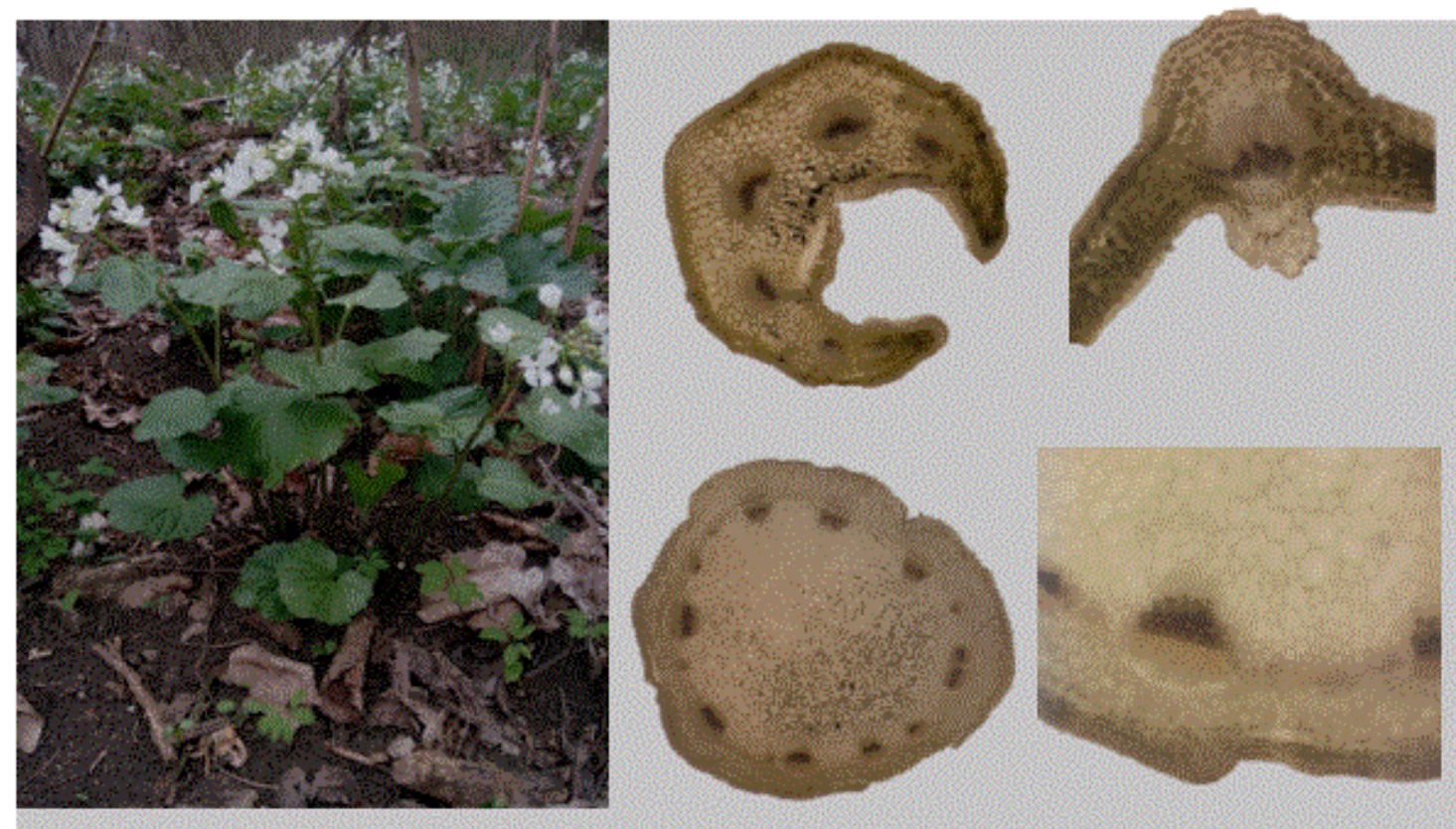

\section{ABOUT AUTHORS}

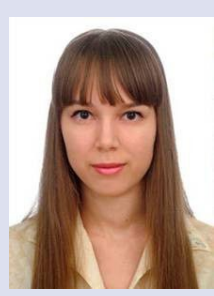

Fedotova Victoria Vladimirovna, Candidate of Pharmaceutical Sciences, Lecturer, Department of Pharmacognosy, Botany and Technology of Phytopreparations of Pyatigorsk Medical and Pharmaceutical Institute, a Branch of Volgograd State Medical University Ministry of Health of Russian Federation. Area of expertise: Pharmacognosy, Phytochemistry, Study of Solidago caucasica and Pachyphragma macrophyllum, Biosynthesis of silver nanoparticles.

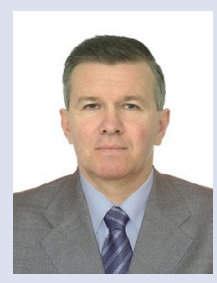

Konovalov Dmitry Alexeevich, Doctor of Pharmaceutical Sciences, Professor, Head of the Department of Pharmacognosy, Botany and Technology of Phytopreparations of Pyatigorsk Medical and Pharmaceutical Institute - branch of Volgograd State Medical University of the Ministry of Health of Russia. Area of expertise: Phytochemistry, Pharmacognosy, Sesquiterpenic lactones, Polyacetylene compounds.

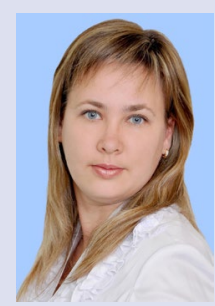

Kruglaya Anna Aleksandrovna, Candidate of Pharmaceutical Sciences, Docent, Department of Pharmacognosy, Botany and Technology of Phytopreparations of Pyatigorsk Medical and Pharmaceutical Institute, a Branch of Volgograd State Medical University Ministry of Health of Russian Federation. Area of expertise: Pharmacognosy, Phytochemistry, Study of Inula sp., Anatomical study of medicinal plants.

Cite this article: Fedotova WV, Konovalov DA, Kruglaya AA. Anatomical Study of Pachyphragma macrophyllum (Hoffm.) N. Busch. Pharmacog J. 2019;11(6)Suppl:1587-90. 